\title{
HISTORY OF SCIENCE AND TECHNOLOGY IN INDIA AND SOUTH-EAST ASIA
}

\begin{abstract}
THE history of the sciences, pure and applied, in India and other parts of South Asia, still remains the greatest 'unknown continent' in this world of study, so important for the general cultural history of mankind. It was therefore an excellent idea to gather together in November 1950 a group of Indian and South Asian scholars interested in the history of science, and to publish, even if only in a provisional form*, the papers which were read to the symposium. The result shows clearly that there is an enormous amount of material already available for the work of synthesis, in which we must attempt to place the development of science and scientific thought in India in its proper framework of parallel developments, some later, some earlier, in Europe and in other parts of Asia. It is also clear, however, from the papers in this symposium, that the task is perhaps the most difficult of all those which face historians of science to-day, owing to the extreme uncertainties in the dating of the most important texts, and even of actual objects which have survived.
\end{abstract}

Some of the papers, such as the general surveys given by A. S. Altekar and by R. C. Majumdar, are judicious and careful concerning this, and will no doubt be in greatest demand if copies are available separately. Some of the specialized papers (such as that by B. L. Raina) are also reasonably cautious. Unfortunately, this cannot be said of the majority of the papers, which put forward quite unacceptably early datings especially for texts purporting to date from the first two millennia B.C. ; particularly bad examples are the two papers on astronomy (by Shukla and Dixit) as well as others on chemistry (by N. R. Dhar), embryology (R. V. Seshaiya) and medicine (G. V. Satyanarayanamurthi). The accom. panying table shows the divergence of opinion. It is even maintained that the Babylonians owed the sexagesimal division of the circle and the system of twenty-eight lunar mansions to India. In general, we find throughout the papers too marked a chauvinistic tendency, an effort to minimize foreign influences on Indian science and to emphasize all outward transmissions - this is, of course, all too easy so long as Indian history has not been provided with a strict chronology. Typical of the desire to make a case is the praise bestowed upon the potters of the Mohenjodaro civilization ( $P$. Ray), where no comparison is made with other pottery products studied by the author, nor is any ceramics expert cited whose opinion might carry weight. Along with these tendencies goes the fault of trying to read too much into ancient texts, as when the Pillar Edicts of Asoka or the text of the "Arthashastra" are appealed to as evidence for advanced fishery legislation (S. L. Hora); here the writer is roundly taken to task by a colleague (R. C. Majumdar). But great uncertainty seems to reign, for the sceptic himself seems to be perhaps too sceptical regarding the military use of arsenical smokes-which were certainly developed quite early by the Chinese. So while most of the writers are too rash, others are too modest, notably

* Proceedings of a Symposium on the History of Science and Technology in South Asia, Delhi, Nov. 1950. Organized by Unesco, and obtainable in mimeographed form from the Unesco Field Science Cooperation Office, c/o University of Delhi. About 150 pp., mostly single-spacing, mimeographed foolscap-size typescript. the writer on Siam (P. Rochanapurananda), who disclaims any contribution of his own Thai people to science, failing to mention the work of la Loubère* in the seventeenth century, which shows that Europeans were at that time much interested in what the Siamese knew. Even if this turned out to be mostly Chinese-as it did-Siam must certainly have had something to show in fields such as textile technology. The same applies to the paper on Indonesian culture (Prijohutomo).

Until the problem of the dating of Indian texts is solved, all those of transmission must remain impossible to deal with. Hence the confidence shown by papers such as that on Indian-Chinese relations (P. C. Bagchi) is entirely misplaced. We cannot admit the derivation of the Chinese lunar mansions from India (probably both systems are ultimately Babylonian). It is absurd to claim Indian influence on a mathematical work such as the "Sun Tzu Suan Ching" (third century A.D.) on the ground that the word 'Ching' was afterwards used for translating the term 'Sutra' in Buddhist texts-all canonical books were known as 'Ching' from the time of the Warring States (fourth century B.c.). Nor is there any mention in this paper of the numerous cases which have been noted of the reappearance of Chinese mathematical problems in subsequent Indian texts.

Nevertheless, the study of the history of science in India remains enthralling. The following words of Filliozat, in the preface to his recent splendid monograph on the theories of classical Indian medicine $\dagger$, are well worth pondering :

"Some may doubt the legitimacy of placing Indian and Greek science on the same level, preferring to compare the former rather with that of Islam. The common opinion that Indian science lacked originality presupposes that it was derived from Greek science, and is therefore sister to the science of the Arabs. . . .

"This problem has been far too much prejudged. Indian scholars, moved by national pride, are prone to maintain that their sciences in high antiquity surpassed even those of to-day. In the West, on the other hand, many maintain that the spirit of scientific research could only have been born in Europe, and that what science the Indians had they borrowed. In either case the only proofs presented are a few examples claimed as characteristic and used as the basis for generalizations, hypotheses taking the place of facts which are still undiscovered or which people will not take the trouble to seek. Indeed, opinions rest on racial or national preconceptions rather than on a profound comparative study of the two great scientific traditions the value of which is to be determined. One notes also that those who speak with the greatest certainty in these matters are just those who are familiar with only one of the two traditions, knowing the other only by scattered facts, or studies which they are unable to appreciate. To say nothing, of course, of those 'authorities' who know nothing of either of the two traditions about which they speak.

* "A New Historical Relation of the Kingdom of Siam...", tr. + Filliozat, J., "La Doctrine Classique de la Médecine Indienne", Imp. Nat. (CNR'S and Geuthner, Paris, 1949). 


\begin{tabular}{|c|c|c|c|c|}
\hline & $\begin{array}{c}\text { Dating } \\
\text { accepted } \\
\text { by critical } \\
\text { modern } \\
\text { scholar- } \\
\text { ship (and } \\
\text { in papers } \\
\text { by A.S. } \\
\text { Altekar } \\
\text { and R.C. } \\
\text { Majumdar) }\end{array}$ & $\begin{array}{c}\text { Papers by } \\
\text { K. R. } \\
\text { Dixit and } \\
\text { G. V. } \\
\text { Satyan- } \\
\text { arayana- } \\
\text { murthi }\end{array}$ & $\begin{array}{l}\text { Paper by } \\
\text { K. S. } \\
\text { Shukla }\end{array}$ & $\begin{array}{l}\text { Papers by } \\
\text { P. Ray, } \\
\text { S.I. Hora } \\
\text { and R. V. } \\
\text { Seshaiya }\end{array}$ \\
\hline Vedic material & $\begin{array}{l}\text { c. }-14 \text { th } \\
(-1400 / \\
-1000)\end{array}$ & $\begin{array}{r}-6000 / \\
-1500\end{array}$ & $\begin{array}{r}-4000 / \\
-2000\end{array}$ & \\
\hline $\begin{array}{l}\text { Upanishads } \\
\text { period } \\
\text {. }\end{array}$ & $\begin{array}{l}-10 \text { th to } \\
-6 \text { th }\end{array}$ & $\begin{array}{r}-17 \text { th/ } \\
-7 \text { th }\end{array}$ & & $\begin{array}{r}-2500 l \\
-2000\end{array}$ \\
\hline $\begin{array}{l}\text { "Jyotisha } \\
\text { Vedanga", }\end{array}$ & $\begin{array}{l}-600 / \\
-200\end{array}$ & & -1400 & \\
\hline $\begin{array}{l}\text { "Surya } \\
\text { Prajnapti" } \\
\text { Astronomical text: }\end{array}$ & c. -400 & & -500 & \\
\hline "Surya & $\begin{array}{l}+4 \text { th or } \\
+5 \text { th }\end{array}$ & & \pm 0 & \\
\hline $\begin{array}{l}\text { Economic and } \\
\text { technological } \\
\text { text : }\end{array}$ & & & & \\
\hline $\begin{array}{l}\text { "Arthashastra" } \\
\text { Medical and bio- }\end{array}$ & $-1 s t$ & & & -4 th \\
\hline $\begin{array}{l}\text { logical texts : } \\
\text { "Susruta } \\
\text { Samhita", }\end{array}$ & $\begin{array}{l}\text {-1st } \\
\text { (present } \\
\text { text } \\
+11 \text { th) }\end{array}$ & -7 th & & -6 th \\
\hline $\begin{array}{l}\text { "Charaka, } \\
\text { Samhita" }\end{array}$ & $\begin{array}{c}\text { +lst } \\
\text { (present } \\
\text { text } \\
+8 \text { th) }\end{array}$ & -7 th & & -6 th \\
\hline
\end{tabular}

"The greatest historians of science have not always escaped from the inconvenience of knowing only one side of the matter. Paul Tannery, so famous for his studies on ancient mathematics, is an example. We know that the trigonometric sine is not mentioned by Greek mathematicians and astronomers, that it was used in India from the Gupta period onwards (+3rd. century), that the Surya Siddhanta (+4th. or +5th. century) gives a table of sines, that the Arab astronomers knew them from their Indian contacts and passed them on to Europe in the +12th. century, when the work of al-Battani was translated into Latin. The only conclusion possible is that the use of sines was an Indian development and not a Greek one. But Tannery, persuaded that the Indians could not have made any mathematical inventions, preferred to assume that the sine was a Greek idea not adopted by Hipparchus, who gave only a table of chords. For Tannery, the fact that the Indians knew of sines was sufficient proof that they must have heard about them from the Greeks.

"If this is the way we are to argue, there was never any science other than Greek science, and the question whether science has any origins other than the Greek 'miracle' is solved in advance. Only a profound study of Indian scientific developments in parallel with those which took place elsewhere about the same times, can reveal the degree of originality of that science, and hence enable us to understand the rôle which India played in the history of the growth of man's knowledge of Nature."

In the present symposium, the writer on Siam ends, somewhat" pathetically: "At present we all seem to believe that science is something which originated especially in Europe and the Near East, and that the Far East had no share in the building of this most important branch of human knowledge. Yet Asian countries such as India and China were important centres of culture both materially and spiritually. Their peoples had learned how to control the natural world around them, and to live a life in which there was room for leisure, only it seems that the knowledge gained by them never joined up with what we know today as modern science. However, Asian people now find no difficulty in learning science and do not lack ability in scientific research."

In my opinion, future research on the history of science and technology in Asia will, in fact, reveal that the achievements of these peoples contributed far more, in all pre-Renaissance periods, to the development of world science than has yet been realized. The programme of Filliozat is the answer to the perplexity of Rochanapurananda. JOSEPH NEEDHAM

\section{WAGNER CHANGES, SYNARTETIC ACCELERATION AND SYNARTETIC IONS}

\author{
By F. BROWN, Prof. E. D. HUGHES, F.R.S., \\ PRoF. C. K. INGOLD, F.R.S., and J. F. SMITH \\ University College, London, W.C.I
}

T $T$ has been established ${ }^{1}$ that the Wagner rearrange1 ment is a form of unimolecular nucleophilic substitution or elimination $\left(S_{N} 1, E 1\right)$; its primary step is that of all such unimolecular reactions, namely, a heterolysis with the production of a carbonium ion. Let us, for present convenience, call the obvious structure for this ion that of the 'first' carbonium ion. This ion might simply take up an anion $\left(S_{N} \mathrm{l}\right.$ substitution), or lose a proton ( $E \mathrm{i}$ elimination). However, the characteristic phenomenon of a Wagner change is that, prior to any such occurrence, a carbon atom with its full octet shifts over from an adjoining position to the charge-centre of the first ion. If nothing else happened, this would produce what we might call the 'second' carbonium ion. It is from this that the rearranged products may be considered as derived, either by uptake of the originally separating anion (Wagner isomerization), or by uptake of a different anion (Wagner substitution), or by loss of a proton (Wagner elimination):

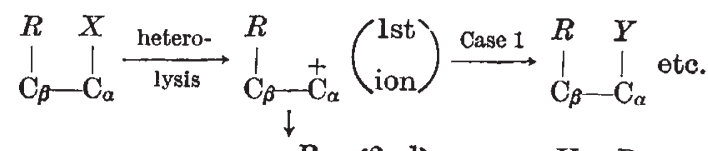

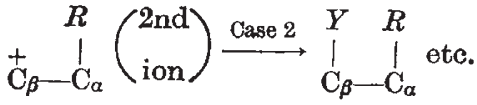

As shown earlier ${ }^{2}$, some primary heterolyses are 'accelerated' ; that is, they occur much more rapidly than when the bond undergoing fission has the same local surroundings in simpler molecules; some heterolyses are not accelerated. Also, some hetero. lyses involve Wagner rearrangements, and some do not. The relationship between incidence of acceleration and of the Wagner change requires analysis.

One possible mechanism for the acceleration of a primary heterolysis depends on the release, during the process, of initially stored non-bonding energy : this has been defined" as 'steric acceleration'. Obviously it might operate whether a Wagner change is involved or not. Another mechanism of accelera. 